\begin{tabular}{lll}
\hline Insan ve Toplum Bilimleri Dergisi \\
VAKIF ÜNIVERSITESI
\end{tabular}

\title{
Osmanlı Türkçesinin Öncü Bağlaçları Hakkında
}

Özet

Ahmet Şefik Şenlik *

Osmanlı Türkçesinde önermeleri, dolayısıyla önermelerin biçimsel karşılıkları olan cümle(cik)leri birbirleriyle irtibatlandırmak için muhtelif imkanlar mevcuttur. Bu imkanlardan biri de aslen Türkçe olmayan, bağlaçlarla teşkil edilen bağlama tekniğidir. Türkçenin kendine mahsus aslî teknikleri olmasına rağmen bağlama tekniği yabancı diller tesiriyle oldukça yaygın bir kullanım alanı bulmuştur. Osmanlı Türkçesinde bu tür büyük yapısal değişikliklere yol açan dil Farsçadır; bağlaçlarla cümle bağlama tekniği de Farsçayla olan dil münasebetlerinin bir neticesi olarak ortaya çıkmıştır. Farsçada kullanılan bağlaçların aynı kullanım ve görev alanına tıpatıp Türkçede de sahip olmaları beklenemez. Daha önceki çalışmalarımızda bağlaçları, cümlelerin oluşturduğu kombinasyonlar içerisinde aldıkları yere göre yeni bir isimlendirme, yeni bir tanım ve tasnife tabi tutmuştuk. Bu yeni tasnifte göre üç alt grup söz konusudur:
1) Aracı bağlaçlar
2) Öncü bağlaçlar
3) Artçı bağlaçlar

Bu makalede ikinci grupta yer alan, Osmanlı Türkçesinin çūn (ki), kaçan (ki), mādām (ki), hemān (ki) gibi öncü bağlaçlarına kısaca temas ediliyor.

Anahtar kelimeler: Osmanlı Türkçesi, söz dizimi, birleşik cümleler, yabancı dil tesiri, bağlaçlar, öncü bağlaçlar

\section{On Prepositive Conjunctions of Ottoman Turkish}

\section{Abstract}

In Ottoman Turkish there are various possibilities to connect propositions, i.e. to link sentences or clauses. One of these possibilities is the linking strategy with conjunctions, which is not a genuine Turkish technique. Even if Turkish has its own techniques to link sentences/clauses, that technique became widely accepted through foreign influence. The language, which caused considerable structural changes in Ottoman Turkish, is the Persian language. The linking strategy with the conjunctions in Ottoman Turkish is a product of Persian influence. We cannot expect the same usage and functions in both languages,

* Yrd. Doç. Dr., İstanbul Medeniyet Üniversitesi Türk Dili ve Edebiyatı Bölümü, İstanbul/ Türkiye, as.senlik@gmail.com 
in Persian and in Ottoman Turkish. In our previous contributions we have suggested new terms, new descriptions and a new classification made according the positions of conjunctions in the combination of sentences. In this classification there are three subgroups of conjunctions:

1) Interface conjunctions

2) Prepositive conjunctions

3) Postpositive conjunctions

In this paper we will deal with the second group, with the prepositive conjunctions of Ottoman Turkish, like çūn (ki), qaçan (ki), mādām (ki), hemān (ki) etc.

Keywords: Ottoman Turkish, syntax, complex sentences, conjunctions, prepositive conjunctions, influence of foreign languages (Persian) on Turkish 


\section{Giriş}

Daha önce yayımlanan bir makalemde Osmanlı Türkçesinin bağlaçlarını muhtelif özelliklerine göre yeniden tasnif etmeye ve kısmen yeniden adlandırmaya çalışmıştım. ${ }^{1}$ Tasnif kıstaslarından birisi de bağlacın birbirleriyle bağlanan cümlelere izafeten bulunduğu yerdi. Bu durumu söz konusu makalede şöyle ifade etmiştim: "Bağlaçları, birbirleriyle bağlanan iki cümleden oluşan bütün içerisinde tercih ettikleri pozisyonlara göre üç grupta toplamak mümkün. (A) ve (B) cümlelerinin birbirinden ayrı birer fiziksel alan olduğunu ve bu fiziksel alanlar arasında da bir sınır bulunduğunu tasavvur edecek olursak, bağlaçların (A) ve (B)'ye ilişkin konumları da, ya sınırda ya sınırdan önce ya da sınırdan sonra olacaktır. Buna göre bağlaçlar, aracı (sınırda), öncü (sınırdan önce) ve artçı (sınırdan sonra) bağlaçlar şeklinde adlandırılıp tasnif edilebilirler".2

İfade edilenler 1şığında birinci sıraya (A) ikinci sıraya (B) cümlesini koyduktan sonra cümlelerin fiziki sınırlarını parantez ile çevreleyip cümle unsurlarını '- ' işareti, bağlacı da 'b' ile temsil edecek olursak şu bir kaç farklı yapı ve bağlaç türü ortaya çıkar:

1. Aracı bağlaçlar: $(---) \mathbf{b}(---)$

2. Öncü bağlaçlar: $\mathbf{b}(---)(---)$ ya da $\left(-\mathbf{b}-{ }_{-}\right)(---)$

3. Artçı bağlaçlar: (- - $)(-\mathbf{b}--)$

İşbu makalede, tasnifte ikinci sırada yer alan öncü bağlaçların Osmanlı Türkçesindeki durumlarına temas edilecek.

Bitimli ('finite') morfolojiye sahip iki cümle arasındaki fiziki sınırdan önce yer alan ve bu sebeple öncü bağlaçlar olarak adlandırdığım bağımsız dil birimleri, söz konusu cümleleri sentaks bakımından birbirlerine bağlama kudretine sahiptirler. Bu tür dil birimleri, dolayısıyla bu birimlerle cümle bağlama tekniği Türkçenin aslî kurgulama sisteminin bir parçası değildir. Fakat münasebette bulunulan Hint-Avrupa dillerinden alınan öncü bağlaçlara Eski Uygurcadan ${ }^{3}$ itibaren tarihî ve çağdaş birçok Türk dilinde/lehçesinde rastlanır.

Osmanlı Türkçesi söz konusu olduğunda öncü bağlaçlarla cümle bağlama tekniği için kaynak dil, Hint-Avrupa dil ailesinin İran dilleri alt grubunda yer alan Farsça olur. Mevzuubahis birimler Farsçada, cümle bağlama ameliyesinde alta sıralayıc1, bağımlılaştırıcı (subordinative) bir işlev görürler. Osmanlı Türkçesinde bu işlevi gören kelimelerin çoğu köken itibarıyla Farsça olmakla birlikte, bazı

1 Ahmet Şefik Şenlik, "Eski Anadolu ve Osmanlı Türkçesinde cümle bağlaçlarının tasnifine dair bazı öneriler", İstanbul Üniversitesi Edebiyat Fakültesi, Türk Dili ve Edebiyatı Dergisi, vol. 45, no. 45 (2011), s. 251-268, 2012a.

2 Şenlik, a.g.e., s. 257-258.

3 Bu devrede söz konusu olan Hint-Avrupa dili, İran dilleri alt grubunda yer alan Soğdcadır. 
bağlaçların teşekkülünde Arapça kelimeler de yer alır (wakt, māa-dām(e) gibi). Malum olduğu gibi Arapça menşeli kelimeler için Türkçeye kaynaklık eden dil, ekseriyetle Farsçadır, bizatihi Arapça değildir. Bu doğrultuda bağlaçların yapısında bulunan Arapça kelimeler de doğrudan Arapçadan alınmamışlar, Türkçeye Farsçanın süzgecinden geçtikten sonra girmişlerdir. Bu birimlerin bazen de Türkçe kökenli bir kelimenin Farsçadaki bağlacın görevlerini kısmen veya tamamen üstlenmesi neticesinde oluşmuş olduğu görülür (kaçan, kim gibi). Burada Farsçadan sadece bağlaçların kendilerinin kelime olarak değil, işlevlerinin ve bağlama tekniğinin de kopyalanmış olduğu, önemle vurgulanması gereken bir husustur; yani bir ifade kalıbı tamamen ya da kısmen kopyalanmıştır. Böylece kopyalama hadisesi kelime boyutuyla sınırlı kalmayıp sentaktik boyuta ulaşmış olur.

Yukarıda da belirttiğim gibi (A)-(B) birleşik cümlesine izafeten öncü bağlacin bulunduğu konum şu şekilde gösterilebilir:

1. Bağlaç, b (- - $)(--\infty)$ kalıbında olduğu gibi (A) cümlesinin başlangıç pozisyonundadır. $\mathrm{Bu}$, en yaygın olan durumdur.

2. Öncü pozisyon grubuna bağlacın iki cümle arasındaki sınırdan önce, (A) cümlesinin sınırları içerisinde yer aldığg fakat başlangıç konumunda bulunmadığ 1 ( - b - - ) ( - - - yapısı da dâhildir ki bu durum bazen sadece ihtiyari değil, aksine zaruridir. Müstakil bir halde iken zaman cümlesi kurma kabiliyeti de olan ki/kim, söz konusu görev için mecburi olarak bu pozisyonu alır (bkz. aşağıda ki/ kim).

Türkçenin edatları ve bağlaçları hakkında kimisi monografi hacminde olmak üzere bazı çalışmalar mevcuttur. Bunlar çok zengin bir malzeme ihtiva etmekle birlikte tanım ve tasnif bakımından maalesef pek tatminkâr değildirler. Birçok çalışmada farklı sentaktik kategorilerde değerlendirilmesi gereken gerçek bağlaç, zarf bağlaç ve diskur bağlacı gibi dil birimlerinin ayırt edilmeksizin aynı kefeye konduğu görülmektedir. Ayrıca farklı nitelikler taşıyan birçok gerçek bağlaç da yine her hangi bir tasnife tabi tutulmadan ele alınmıştır. Bu tür meselelerin üstesinden gelebilmek için her şeyden evvel bağlaçların sentaktik ve semantik görevlerinin ayrı ayrı tesbit edilmesi ve bu görevlere uygun olarak değerlendirmeye tabi tutulmaları gerekmektedir.

Öncü bağlaçlarla bağlanan cümleler, yan cümle(cik)lerdir ve ana cümleye zarf işleviyle bağlanıp zarf anlamı verirler. Bu surette oluşturulmuş yan cümleleri Johanson (1993 ve 1996), 'yoğun yabancı dil etkisinde kalmış kombinasyon kalıpları' ("stärker fremdbeeinflußte Kombinationsmuster") olarak adlandırıyor ve bunların birleşik cümle hiyerarşisi içerisinde belli nisbette bir geri kademelen- 
dirmeye maruz kaldıklarını ifade ediyor. ${ }^{5} \mathrm{Bu}$ durumda bağlanan/bağımlılaştırılan cümlenin içeriği, anlatı değeri bakımından birincil bir öneme sahip olmuyor, kapsayıcı cümle içeriği ile eşdeğer bir bilgi ihtiva etmiyor; artık tali bir malumat halini alıyor. Bununla birlikte bu yapılar zarf fiil ekleri vasıtasılyla, Türkçenin kendine mahsus yöntemleri kullanılmak suretiyle bitimsizleştirilen yüklemlerin/ cümlelerin imkanlarına nazaran yine de bazı serbestîlerden yoksun bulunuyor. Nitekim temel cümle (B), bağlanan cümle (A) ile birlikte bu ikisini birlikte kapsayabilecek bir cümlenin (C) içine Türkçe yöntemlerle entegre edilemiyor. ${ }^{6}$

Osmanlı Türkçesinde öncü bağlaçlarla kurulan birleşik cümlelerde - Latin alfabesine göre - solda yan cümle (A) bulunur ve bu cümle sağdaki temel cümleyi (B) açıklar mahiyette bir tali malumat ihtiva eder. Bağlacın gayet tabii bir anlamı vardır ve cümleleri bu anlam ilişkisiyle semantik bakımdan irtibatlandırır. Fakat bu anlam genellikle Türkçe zarf fiil yapılarının ifade edebileceğinden daha spesifik değildir. Anlam alt kategorileri genellikle metnin gidişatından anlaşılır, bağlacın kendisinden değil. Öncü bağlaçlarla kurulan (A) cümleleri Osmanlı Türkçesinde ekseriyetle zamana ilişkin bir fikir ifade ederek (B) temel cümlesine bağlanırlar. Fakat zaman fikri, yegane semantik kategori değildir. (A) cümleleri sebep-sonuç, şart, zıtlık, karşıt sebep gibi anlam ilişkilerine dair malumatlar da verebilirler. Öncü bağlaçlarla bağlama tekniğinin adaptasyonunda ve yaygınlaşmasında Türkçe cümlenin sola doğru genişleyici yapısının kolaylaştıııcı bir amil olduğu düşünülebilir.

Her şeyden evvel bu tasnifin genel temayülleri aksettirmek niyetiyle yapıld1$\breve{g} ı n ı$, istisnaların da bulunabileceğini belirtmek lazım. İstisnalar muhtelif saiklerle ortaya çıkabilirler; tercümelerde orijinal metindeki söz sıralamasına sadık kalınmak suretiyle ortaya çıkan takdim-tehir durumu buna bir örnek teşkil edebilir. Bazı bağlaçlar birden fazla, farklı pozisyonlarda kullanılabilirler. Böylece farklı kombinasyonlar oluşturarak farklı fikirler ifade ederler. Mesela dahı için hem aracı hem artçı kullanım söz konusu olabilir, keza ki/kim için muhtelif kombinasyonlarla hem aracı hem öncü. Yine genellikle ara pozisyonda kullanılan anu¡içün ki/kim bağlacının bazen öncü bağlaç olarak kullanıldığı görülür. Bazen de aslında öncü pozisyonu tercih eden bağlaçların (kaçan gibi) tercüme sebebiyle orijinal metindeki bağlacın yerine gelecek şekilde aracı olarak kullanıldığı görülebilir. Buna mukabil bazı bağlaçların pozisyonları değişmez, yalnızca aracı olan ve gibi.

Şart eki alan cümleler (eger, kaçan, vs. gibi) bir öncü bağlaç ihtiva ediyor olsalar dahi bu incelemeye dahil edilmemiştir. Zira bu cümlelerde asıl bağlayıcı

5 Lars Johanson, “Typen kausaler Satzverbindungen im Türkischen”, Journal of Turkology 1 (2), yay. haz. Á. Berta, \& Á. Molnár, s. 213-267; Szeged, 1993.

Lars Johanson, "Kopierte Satzjunktoren im Türkischen”, Sprachtypol. Univ. Forsch. (STUF), 49 (1996)-1, s. 39-49, 1996.

6 Bkz. Şenlik, a.g.e.; krş. Johanson, a.g.e., 1993, s. 258. 
unsur şart ekidir; bağlaç burada sadece anlam çeşitlenmesine yardımcı olur. $\mathrm{Bu}$ tür cümlelerin melez yapılar olarak adlandırdığım ayrı bir kategoride ele alınması gerektiğini düşünmekteyim.

İncelemede yer alan örnek metinler 15 ilâ 17. yüzy1llar nesrinden seçilmiştir.

\section{- çūnki}

Bu bağlacın Osmanlı Türkçesinde öncü bağlaçlar arasında yaygınlık bakımından özel bir yeri vardır. Arap yazı sistemine göre ki/kim kısmının bitişik de ayrı da yazıldığı vakidir; bağlaç metinlerde şu muhtelif şekillerde göze çarpar: çūnki, çūn ki, çūnkim, çūn kim, çūn. Burada grafik özelliği aksettirmesi maksadıyla verdiğim uzun $\bar{u}$ ünlüsü, en azından 16. yüzyıldan itibaren kısa $\ddot{u}$ olarak telaffuz edilmekte idi, yani çünki olarak. Adamović kelimeyi 16. yüzyılda "ciunchi” "çünki' şeklinde tespit etmiş. ${ }^{7}$ Yine 17. yüzyıl sözlükçüsü Meninski, harf-i ta 'līl $l^{8}$ olarak belirttiği bağlacı kısa $\ddot{u}$ ile, yani "ćiün/ćiünḱi”" 'çün/çünki' olarak veriyor. ${ }^{9}$ Buna mukabil yine Farsçadan alınan, aynı imla ile yazılan fakat "nice, nite, keyfe" manaları ile açıklanan çūn (ćiūn) kelimesini uzun $\bar{u}$ ile veriyor. ${ }^{10}$ Demek ki o dönemde sadece anlam ve işlev bakımından değil, telaffuz bakımından da farklı bir çūn mevcuttu.

Osmanlı Türkçesinde olduğu gibi, menşe dil Farsçada da iki farklı anlam ve işleve sahip olan bu homograf, aslında aynı temel tasavvur ve terkipten neşet etmiştir. Modern Farsçada çon/çun olarak bildiğimiz bu kelimenin artzamanlı düzlemde mana ve işlev bakımından seyri ilginçtir. Kelime, soru zamiri çi (çe(h)) 'ne' ve Avesta devresinin isim soylu kelimesi gaona-'nın 'renk' birleşmesinden oluşmuştur; 'ne renk' temel tasavvurundan hasıl olan 'nasıl' anlamı ile Orta Farsçada (Pehlevi) çigūn (=*çigōn) şeklinde, Turfan metinlerinde ise çi'ōn (=*çiyōn) şeklinde geçer. ${ }^{11}$ Yani Yeni Farsçada karşımıza çıkan çon kelimesi aslına bakılırsa tarz/suret ifade eder ve 'nasıl, ne tür, ne gibi' bir anlam taşır. Nitekim kelime, Farsçada (çon/çun//ço/çu) olduğu gibi Osmanlı metinlerinde de (çūn/çün; nazım dilinde bazen $c ̧ \bar{u} / c ̧ u ̈)$ bağlaç olarak kullanımının yanı sıra, '(b)öyle, (b)öylece, bu/o şekilde, nasıl, ... gibi’ vs. anlamlarında tarz ve suret zarfı olarak karşımıza

7 Milan Adamović, Floransalı Filippo Argenti'nin notlarına göre (1533) 16. yüzyıl Türkçesi, (terc. Aziz Merhan). TDK yayınları: 415. Ankara, 2009, s. 154.

8 Meninski, edatı "harf-i ta 'lîl" (sebebiyet edatı) olarak adlandırmış olsa da Latince "quoniam, siquidem, quandoquidem, cum, dum, quando, postquam' ve Almanca 'dieweil/sintemahlen/ weil/wann/angesehen/in Betrachtung/in Ansehung/dessen daß; nachdem als...' anlamlarını veriyor ki bu da bağlacin hem sebep-sonuç hem de zaman ilişkileri kurduğuna delalet ediyor. (Franciscus à Mesgnien Meninski, Thesaurus Linguarum orientalium turcicae-arabicae-persicae, lexicon turcico-arabico- persicum. Tıpkıbasım (2000) M. Ölmez, \& S. Stachowski, İstanbul, 1680, s. I/1685).

9 Meninski, a.g.e., s. I/1685.

10 Meninski, a.g.e., s. I/1684.

11 Paul Horn, Grundriss der neupersischen Etymologie. Strassburg, 1893, s. 100.

Hans Jensen, Neupersische Grammatik. Heidelberg, 1931, s. 88. 
çıkar. Çün imlasıyla yazılan kelime için biri bağlaç, diğeri zarf olmak üzere iki farklı fonksiyon ve buna ilişkin en az iki ayrı anlam söz konusudur. Bağlaç olan çūn, - bu şekiyle, yalın halde de metinlerde geçebilmekle birlikte - ekseriyetle ki/ $\mathrm{kim}$ ile birlikte kullanılır. Zarf olan çūn ise $\mathrm{ki} / \mathrm{kim}$ almaz.

Menges 'çūn' ve 'çū' kelimelerinin Farsçada olduğu gibi Çağataycada da çok anlamlı [işlevli] olduğuna, bunların hem bağlaç hem de edat/zarf olarak kullanıldiğına dikkat çekiyor. ${ }^{12}$ Ama tam da ikaz ettiği hususta kendisi hataya düşüyor. Kanaatimce karşılıklı irtibatı olduğuna, birbirlerini anlamca karşılıklı desteklediğine [bağlaç ve zarf fiil ekinden müteşekkil bir melez yap1 kurduğuna ${ }^{13}$ ] inandığ1 $c ̧ \bar{u}$ ile - gaç, iddiası için hiç de uygun bir misal teşkil etmiyor. ${ }^{14}$ Zira burada çū, bağlaç olarak değil, '... gibi, nasıl, ... nasılsa öyle' anlamında zarf görevinde kullanılmıştır. ${ }^{15} \mathrm{Bu}$ makalede zarf olan çūn/çu aslında bizi fazlaca ilgilendirmiyor; burada kısaca temas edilmesinin sebebi, karıştırmaya/yanlış yoruma mahal verebileceğine dikkat çekmek idi. Biz, 'nasıl ki' tasavvurundan gelişerek cümleler arasında zaman ve sepep-sonuç ilişkileri kurabilen bağlacımız çūn(ki)'ye dönelim.

Eski Anadolu Osmanlı Türkçesi metinlerinde (takriben 19. asra kadar) bağlacın kullanımında Farsçada olduğu gibi öncü pozisyon hakimdir. Yine aynı dönem Farsçasında olduğu gibi bağlaç, bağlanan cümleler arasında hem zaman hem de sebep-sonuç ilişkileri kurmaktadır. Bu iki farklı semantik cepheye öncelikle Deny, bilahare Hacieminoğlu ve Tiken temas ediyor. ${ }^{16}$ Eski Anadolu Türkçesi döneminde Farsçadan yapılan tercümelerde çonke, Türkçede bazen bağlacın kendisi bazen de Türkçenin kendi imkanları ve yöntemleri ile yani $-(y) I c A K,-d U K d A$ gibi Türkçe eklerle kurulan, aspekt ve zaman ilişkilerine aracılık edebilen muhtelif bitimsiz yapılarla karşılanmıştır. ${ }^{17}$

12 Karl Heinrich Menges, Das Čagatajische in der persischen Darstellung von Mīrzā Mahdī Xān. (= Akademie der Wissenschaften und der Literatur, Abhandlungen der geistesund sozialwissenschaftlichen Klasse, 1956 - 9). Wiesbaden, 1956, s. 95.

13 'Melez yapı' tabiri Menges'e ait değil. Bu, benim 2006'da ilgili dil hadisesini tanımlamak üzere Almancada teklif ettiğim 'Hybride' kavramının Türkçe karşılığıdır (bkz. Şenlik, 2006).

14 Menges, a.g.e., s. 40 ve 56.

15 Söz konusu beyit "kilürünge yasadım könglim evin // yasalur külbe çü mihmān kilgeç”tir. Menges bunu Almancaya "Für dein Kommen habe ich das Haus meines Herzens bereitet; die Hütte (aber) wird hergerichtet, wenn der Gast gekommen ist" şeklinde tercüme etmiş (Menges, a.g.e., 40/662). Bunun Türkçesi, Gelmen için gönül evimi hazırladım/düzelttim; Kulübe (ama) misafir gelince/geldikten sonra hazırlanır. Benim kanaatimce anlaşılması gereken ise: Gelmen için gönül evimi hazırladım; misafir geleceği zaman nasıl kulübe hazırlanır(sa öyle) ya da ...kulübenin misafir geleceği zaman hazırlandiğı gibi.

16 Jean Deny, Grammaire de la langue turque (dialecte Osmanli). Paris, 1921, s. 689 ; Hac1eminoğlu, Necmettin, Türk dilinde edatlar. İstanbul, 19924, s.133; Kamil Tiken, Eski Türkiye Türkçesinde edatlar, bağlaçlar, ünlemler ve zarf filller, TDK 837, Ankara, 2004, s. 54.

17 Römer, Claudia, "Der Einfluss der Übersetzungen aus dem Persischen auf die Entwicklung des Osmanischen im 14. und 15. Jahrhundert”, Wiener Zeitschrift für die Kunde des Morgenlandes 73 (Wien), 89-114. 1981, s. 108. 
Cümleler arasındaki semantik münasebetin türü ancak kontekste bağlı olarak tam manasıyla anlaşılabilir. Bununla birlikte gözden geçirdiğim metinlerden yola çıkarak kurulan semantik ilişkinin ekseriyetle bir zaman fikri içerdiğini belirtmem gerek. Çūnki ile bağlanan cümleleri, aralarındaki semantik ilişki bakımından iki temel grupta ele almak gerekir: 1) Zaman ilişkisi, 2) Sebep-sonuç ilişkisi.

1) Çünki ve zaman ilişkisi: Bağlaç, (A) cümlesini zaman ilişkisi ile (B) cümlesine bağlar. Zaman cümlesi bağlacı olarak çūnki Türkçenin zarf filllerle kurabileceği spesifik bir zaman fikrini hiç bir zaman aynı keskinlikte ifade edemez. Zaman fikrinin spesifik türü ancak metne bağlı olarak yorumlanabilir. Burada zaman fikrinden eşzamanlılık, ön zamanlılık, art zamanlılık ve ivedilik vs. gibi alt kategoriler anlaşılmalıdır.

çūnki (hūnkār bu fikrleri istimā' ètdi) (cān ü göyülden kabūl kılup deve tedbìrinden vāz geldi) [istima' edince]

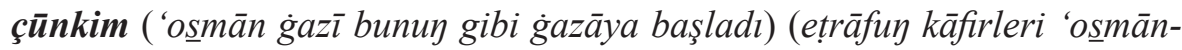
dan ihtizār èdüp üşenür oldılar) [başladıktan sonra/başlayınca ]

çūnki (şāhzāde ve sāyir begler bu haberi aldılar) (cümle ferahnāk olup ölüsi dirlidi ve dirisi yedi başlu ecder oldi) [alınca/aldıktan sonra]

çūnki (karaman og̀lı bu haberi èşiddi) (aḳl başından gidüp nice èdecegin bilmedi) [işitince]

çūn (düzmeydügini bildiler) (i ‘rāż ètdiler șuçlart yokdur) [bilince/bildikten sonra]

çūn ki (pīr aḥmed istiḳlāl buldı) (kuyruġın bulamag்a başladı) [bulunca/bulduktan sonra]

$\mathrm{Bu}$ bağlaç çok yaygın olarak kullanılmakla birlikte bazen Türkçede oluşturduğu yapının çok da sağlam olmadığı intibaını verir. Nitekim hiç ihtiyaç yokken cümlelerin birbirleriyle aşağıdaki örnekteki gibi bir de ve ile bağlandığı görülebilir:

çūnki (tekür yètişdi 'oṣmān ġāzīyle bulışdı) ve (bu 'avrat șūretine giren dilāverler dahı ardın kesdiler) [yetişip buluşunca]

1) Çünki ve sebep-sonuç ilişkisi: Çūnki'nin oluşturduğu sebep-sonuç ilişkisi, umumiyetle salt sebebiyetten ziyade izafi bir sebebiyet fikri içerir. (A) cümlesi bu izafi sebep fikri ile (B) sonuç cümlesine bağlanır. Bu fikri Türkçe zarf fiil yapılarıyla ifade etmek istersek bunun için en uygunu [-DIK/-(y)AcAK + iyelik + Dativ + göre $]$ olur. Yine bazı özel durumlarda $[-D I K+$ Ablatif + sonra $]$ da oluşan bağlama karşılık gelebilir. Bunun gibi günümüz Türkçesinin madem ki öncü bağlacı da bu izafi sebebiyet fikrini verir. ${ }^{18}$ Ayrıca ana cümlenin soru/emir/ünlem/

18 Mehmed Rif'at (Manastırlı), H'āce-i lisān-l 'O $\underline{s} m \bar{a} n \bar{i}, 2$ (Naḥv-i Türkī). Dersa'ādet, 1311 R. (=1893 M.), s. 91. 
retorik soru cümlesi olduğu durumlarda kullanıma gayet de elverişlidir.

çūnki (hâl bu vechile oldı) (cengi qoyup hișārı ulu karındaşuma teslīm ède$\sin )$ [olduğuna göre]

çünki (toğmakdan kalmaduk) (elbette ölmekden dahı kalmazuz) [kalmadığ1miza göre/doğduğumuza göre/doğduysak]

çūnki (sulțān maḥbūs oldı) (çeri şimdengèrü ceng ètmek ne lāzım) [olduğuna göre]

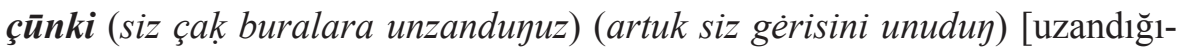
nıza göre]

çūnki (melā'ik hakkdan bizüm ḥālümüze vāḳı olmaģçün ref'-i hicāb țaleb eder) (biz öyümüze hicāb getürmek revā degildür) [talep ettiğine göre/ediyorsa]

Cṣunki (ßen ßefer kișzșzeßinden haberdar degilßen,) (gairi șeyler ßoalideim) [haberdar olmadığına göre] (Hazai 1973: 40)

Bu iki temel semantik kategori dışında bağlacın bazen $-(y) s A$ ekine ihtiyaç duymaksızın şart cümlesi ifadesine imkan sağladığı da görülür.

\{imdi cānum sen dèrsin ki bu kefere țāyifesi bozulmamışdur ya\} çūnkim (bozılmamışdur) (nice oldı bu sizüy yèr götürmez 'askerü̈üz) \{göge mi agdılar ya nice oldılar\} [bozulmamışsa]

Bağlaç takriben 19. asırdan itibaren artık zira gibi aracı bir bağlaç olarak kullanılmaya ve sebep-sonuç ilişkisini sarih bir şekilde ifade etmeye başladı. Ahmed Cevdet (Paşa) durumu "(zīrā) ve (çūnki) mā-ḳablinin sebeb ve 'illeti olan kelāmın üzerine dāhil olurlar" şeklinde ifade eder. ${ }^{1920}$ İran Azericesi gibi Farsçanın tesirinde kalan bazı modern lehçelerde ara pozisyonunda kullanılır. ${ }^{21}$ Zaten çon(ke) modern Farsçada da artık ara pozisyonunda kullanılabilmektedir.

Türkiye Türkçesinde çünkü, (_- - ) b (- - - kalıbı uyarınca artık yalnızca sebep-sonuç ilişkilerinin sarih şekilde ifade edilmesi gerektiği/istendiği durumlarda aracı bağlaç olarak kullanılır. Latin yazı sistemine göre soldaki cümle (A) sonuç, sağdaki (B) ise sebep cümlesidir: [(sonuç) çünkü (sebep)]. Yani sebep-sonuç kısımlarının yerleri bağlamında bir takdim-tehir söz konusudur. Bu pozisyon ve mana değişimi nisbeten geç bir gelişmedir. Edatın Türkiye Türkçesinde aracı bağlaç olarak kullanılması ilgi çekici bir hadisedir. Bu pozisyon değişiminde çūnki’nin Eski Anadolu ve Osmanlı Türkçesi devrelerinde ekseriyetle

19 Ahmed Cevdet (Paşa), Belāgat-ı 'Osmāniye, İstanbul, 1298 R. (= 1882 M.). (1298(H), s. 114.

20 Krş. Mehmed Rif'at, a.g.e., s. 91.

21 Krş. Filiz Kıral, Syntaktische Einflüsse des Persischen auf das gesprochene Aserbaidschanisch von Iran. [Diss.], Mainz, 1997, s. 114; Tadeusz Kowalski, Sir Aurel Stein's Sprachaufzeichnungen im Ä̈nallu Dialekt aus Südpersien (= Polska Akademia Umiejętności. Prace Komisji Orientalistycznej - 29.), 1937. s. 31. 
aracı olarak kullanılan anuฑiçün ki bağlacı ile fonetik ve semantik benzerliğinin etkisi olduğu kuvvetle muhtemeldir (krş. Johanson 1996: 45; Şenlik 2012b).

Türkiye Türkçesinde çünkü'nün bağladığı cümleler, sentaks hiyerarşisi bakımından aynı seviyededirler; tahkiye içerisindeki anlatım değerleri de aynı derecededir; çünkü cümleleri tali malumat vermezler, aksine bağlandıkları cümle gibi onlar da anlatım değeri bakımından öncelikli bir bilgi veririler. Bu noktada Underhill'in "çünkü; çünki”"yi Türkiye Türkçesinde "subordinating conjunctions" olarak tasnif etmesi ise kabul edilemez. ${ }^{22}$ Zira burada bağlanan cümleler hiyerarşik bakımdan eşdeğerlidir. Dolayısıyla ancak bir coordination söz konusu olabilir.

Günümüz Türkçesinde kullanılan çünkü'nün pozisyon ve anlamından yola çıkarak Osmanlı Türkçesindeki çūnki'yi izah etmeye çalışmak şüphesiz hatalı sonuçlara götürür. Bulut, Evliya Çelebi metinlerinde, sanki bu devrenin karakteristik bir özelliği değilmiş gibi, bağlacın öncü pozisyonunu oldukça dikkate şayan bulur. ${ }^{23}$ Harf Devrimi sonrasında Arap harflerinden Latin harflerine aktarılmış kimi metinlerde de bazen çūnki'nin öncü bir bağlaç olduğunun anlaşılmadığı, bilakis bir aracı bağlaç olarak görüldügüu, dolayısıyla noktalama işaretlerinin yanlış konduğu gözlemlenmektedir. Tabii bu da okuyucunun metni yanlış anlamasına sebebiyet verir.

\section{- ki / kim}

Farsçadan alınan $k^{24}$ ve onun görevlerini üstlenen Türkçe kökenli kim ${ }^{25}$ Osmanlı metinlerinde birçok farklı pozisyon, kombinasyon, anlam ve fonksiyonla karşımıza çıkabilir. Bağlaç, bu fonksiyon ve mana çeşitliliği içerisinde bir de zaman zarf cümlesi kurar. Bu tür bir zaman zarf cümlesinin kurulabilmesi için bağlacın bulunduğu pozisyon çok önemlidir.

Bu cümlelerde kullanılan ki/kim gerçi öncü bir bağlaçtır, yani zaman cümlesi olarak yorumlanabilecek cümlenin (A cümlesinin) yükleminden önce yer alır fakat hiç bir zaman, diğer öncü bağlaçlarda olduğu gibi birinci pozisyonda, bir

22 Robert Underhill, Turkish grammar, Cambridge, Mass. \& London, 1976, s. 435.

23 Christiane Bulut, Evliya Çelebis Reise von Bitlis nach Van. Ein Auszug aus dem Seyahatname. (= Turcologica 35, yay. haz. Johanson, L.),Wiesbaden, 1997, s. 121.

24 Farsçada ke bağlacının geniş kapsamlı bir kullanım alanı vardır; nesne cümlelerini, muhtelif zarf cümlelerini, ilgi cümlelerini bağladığı gibi birçok mürekkep bağlacın da teşekkülüne iştirak eder. Amin-Madani \& Lutz "persische Universalkonjunktion" 'Farsça çok işlevli bağlaç' ifadesini kullanıyorlar (Sadegh Amin-Madani, \& Dorothea Lutz, Persische Grammatik. Heidelberg, 1972, s. 265).

25 Türkçe soru zamiri kim, bağlaç vazifesini aslında Anadolu devresinden çok daha önce, Eski Uygurca devresinde başka bir İran dili Soğdcanın tesiriyle üstlenmiştir. Soğdcayla başlayan bu tesir, kendisini İran coğrafyasında ve komşuluğunda bulunan Türklerin dilinde Farsça üzerinden pekiştirmiştir. Eski Anadolu ve Osmanlı Türkçesi devrelerindeki müessir İran dili tabii ki Farsçadır. 
cümlenin başlangıç mahallinde görülmez. Farsçada da durum aynıdır. ${ }^{26}$ Benim rastladığım örneklerde bu yer, (A) cümlesi içinde, $\left(-\mathbf{b}--_{-}\right)\left(--{ }_{-}\right)$kalıbındaki gibi umumiyetle cümlenin birinci unsurundan sonra, ikinci sıradadır. Fakat bağlaç, nadir de olsa cümlenin yapısına, uzunluğuna bağlı olarak yüklemden önce olmak şartıyla daha ileride bir yerde de bulunabilir. Bu yapı Osmanlı yazı dilinde yaygın olarak kullanılmıştır. Deny, bu cümleleri "circonstance de temps" 'zaman zarf cümlesi' olarak adlandırır ve "quand, lorsque" '(-DIK+ iyelik + zaman; -(y)IncA ' karşılığını verir. ${ }^{27}$

Kıral, bağlacın pozisyonunu modern İran Azericesi için dikkat çekici buluyor. ${ }^{28}$ Yazarın iddiasına göre zaman bağlacı olan $k i$ yüklemden hemen önce (!) yer alır. Kıral'ın bu görüşü doğru değil, genelleştirilemez. Zira verdiği örneklerde ki bağlacının yüklemden hemen önce oluşunun tek sebebi var, o da cümlelerin yüklem hariç yalnızca tek bir unsurdan oluşması. Bu durumda ki'nin yüklemin hemen öncesinde olmasından başka bir seçenek zaten bulunmuyor. İran Azericesinde bağlaç, pozisyon bakımından kanaatimce Farsçadan ya da Osmanlıcadan daha farklı bir durum sergilemiyor. Türkiye Türkçesinde bu tür zaman cümleleri artık bulunmuyor. 15. yüzyıldan iki örnek verelim:

(şehrüy halkı kim bu 'adli gördiler) (şehrü̈ kapusin açdılar) [görünce/gördüğü zaman]

\section{(mihal kim haber éşitdi) ('alā't-ta 'cūl geldi) [işitince]}

$\mathrm{Bu}$ tür yapılar bazen ki/kim'den hemen sonra gelen cümlenin daha önceki isim cinsli kelime için bir ilgi cümlesi mi yoksa cümlenin bütününün bir zaman cümlesi mi olduğu hususunda yorumlama zorluklarına ve yanlış anlaşılmalara sevk eder. Kerslake, verdiği "Bu türkler ki gelüb bunda tavattun ètdiler, etrāfa el uzatmaġa bašladïlar" 'These Turks who...' örneğinden yola çıarak çok kesin bir dille "Relative clauses were signalled by the relative pronoun ki(m)" yargisina varıyor. ${ }^{29}$ Kanaatimce burada $k i$ ile oluşturulan ilişki pekala zaman cümlesi olarak anlaşılabilir, hatta böyle anlamak daha makuldür. Söz konusu cümlenin nasıl anlaşılması gerektiği hakkında ancak metnin bütününü dikkate almak bize yardımcı olabilir. ${ }^{30}$ Şimdi bu bağlamda aşağıdaki örneği anlamaya çalışalım:

('osmān-l ġāzīkim geldi) (çavdar og̀lın getürdiler) [gelince]

26 Amin-Madani \& Lutz, a.g.e., s. 277.

27 Deny, a.g.e., s. 685.

28 Kiral, a.g.e., s. 108.

29 Celia Kerslake, "Ottoman Turkish”, The Turkic Languages, ed. by Johanson, L. \& Csató, E. Á., s. 179-202, London, 1998, s. 200.

30 Bu yapıların Farsçadaki durumu için bkz. Amin-Madani \& Lutz, a.g.e. ; Bozorg Alavi \& Manfred Lorenz, Lehrbuch der persischen Sprache. Leipzig, Berlin, München, Wien, Zürich, New York, 19947, 206, 109. ; M. Nazif Şahinoğlu, Farsça grameri. Sarf ve nahiv, İstanbul, 1997, s. 632. 
Yüklemi geldi olan cümlenin bir ilgi cümlesi olabileceği kabul edilemez, yani buradan *Gelen Osman Gazi'ye Çavdaroğlu'nu getirdiler anlaşılmaz, aksine Osman Gazi gelince Çavdaroğlu'nu getirdiler anlaşılır.

Farsçada bu türden zaman cümlelerinin arka planında diyakronik bakımdan bir ilgi cümlesi tasavvurunun var olma ihtimali akla gelebilir. Bu mevzu bir genel dil bilimi meselesi olarak çok ilgi çekici olmakla birlikte makalenin çerçevesi dışında kaldığından ayrıntılara giremeyeceğim.

\section{- kaçan}

Türkçe menşeli bir kelime olan kaçan, Soğdcanın tesiriyle Hind-Avrupa tarzı bir bağlacının özelliklerini henüz Eski Uygurca devresinde üzerine alarak zaman zarf cümlesi kurmaya başladı. ${ }^{31}$

Kaçan kelimesinin etimolojik tahlili için bazı öneriler vardır. Clauson, $k a-$ çan'ın hem soru hem de zaman zarfı olduğunu, morfolojik bakımdan açık olmadığını, fakat akla kaç ve ka:ñu:'yu getirdiğini söylüyor. ${ }^{32}$ Vámbéry kelimeyi *kay'dan "kaćan (kajćagun)" 'ne zaman' şeklinde izah ediyor. ${ }^{33}$ Erdal ise *ka + ça (eşitlik) $+n$ (vasita) ihtimali üzerinde duruyor. ${ }^{34}$ Burada söz konusu olan kaçan ile kaçmak fiilinden sıfat fiil ekiyle türetilen ve 'firar eden' anlamına gelen kaçan'ın birbirlerine karıştırıldıkları da vakidir. Nitekim Serebrennikov \& Gadžieva "Kaçan deliler hakkında yeni haberler alındıkça dinleyicilerimize bildirilecektir" cümlesindeki "kaçan bağlacı"nın (!) “-dıkça” ile birlikte melez yapı oluşturduğu kanaatindeler. ${ }^{35}$

Bağlaç kimi zaman tek başına kimi zaman $\mathrm{ki} / \mathrm{kim}$ unsuru ile oluşturduğu kombinasyonla bitimli yüklem morfolojisine sahip bir cümleyi (A cümlesini) zaman zarf cümlesi olarak bir başka cümleye (B cümlesine) [-(y)IncA; $-D I K+$ iyelik + lokatif; $-D I K+$ iyelik + zaman] gibi bir anlamla bağlar.

31 Bkz. Kaare Grönbech, Der türkische Sprachbau. Kopenhagen, 1936 ; Ahmet Temir, "Konjunktionen und Satzeinleitungen im Alt-Türkischen 1", Oriens 9, 41-85, 1956a, s. 77 ; Ahmet Temir, "Konjunktionen und Satzeinleitungen im Alt-Türkischen 2", Oriens 9, 233-280, 1956b, s. 263.

32 Sir Gerard Clauson, An etymological dictionary of pre-thirteenth-century Turkish. Oxford, 1972, s. 592.

33 Hermann Vámbéry, Etymologisches Wörterbuch der Turko-Tatarischen Sprachen, Leipzig, 1878, s. 71.

34 Marcel Erdal, A grammar of Old Turkic. Leiden, Boston, 2004, s. 215.

35 B. A. Serebrennikov \& Ninel Z. Gadžieva, Sravnitelno-istoriçeskaya grammatika tyurskih yazıkov, sintaksis, Moskva, 1986, s. 245; Serebrennikov ve Gadžieva'nın orijinali Rusça olan bu çalışmalarının TDK'dan 1033 numarayla yayımlanmış bir de Türkçe tercümesi var (terc. M. Öner ve T. Hacıyev, 2011). İlgili cümle tercümede 243. sayfada geçmektedir. Fakat bu tercüme genel anlamda aslından çok büyük farklılıklar göstermekte ve büyük eksiklikler ihtiva etmektedir. Dolayısıyla orijinal metne bakmak daha sağliklı sonuçlar verecektir. B. A. Serebrennikov \& Ninel Z. Gadžieva, Türk yazı dillerinin karşılaştırmalı-tarihi grameri. (terc. T. Hacıyev \& M. Öner). TDK yayınları 1033, Ankara, 2011. 
kaçan (bāyezìd han ol vilāyetleri aldı) (anuy begleri bi-küllì 'araba kaçup anda kış̧ladı) [alınca/aldıktan sonra]

kaçan kim (leşker cem' oldı) (burusadan yeji şehre çıkdılar) [cem olunca/ olduktan sonra]

ḳaçankim (ol țopı atalar) (ol zamān her koldan yörüyelüm) [atınca/attıkları zaman]

$\mathrm{Bu}$ bağlaç (B) cümlesi içerisinde yer alan hemāndem/hemān vs. gibi uygun bir zarf bağlaçla irtibatlandırılarak daha spesifik olan ivedilik fikrini de verebilir.

kaçan kim (kıral-ı bed-fi'ālüy başına gelen mușībeti gördiler) (hemāndem küffāruy jupanları ve hersekleri karārı firāra tebdīl èdüp her birisi başın kurtarmak sevdāsına düşüp...) [görünce ... hemen]

Yukarıda bahsettiğim gibi aslında bir öncü bağlaç olan kaçan'ın tercüme sebebiyle orijinal metindeki bağlacın yerine gelecek şekilde ara pozisyonda kullanıldığını da vakidir.

Kaçan'ın kullanıldığı yerler daha ziyade şart eki ile bağlanmak suretiyle oluşturulmuş genelleyici zaman cümleleridir (kaçan (ki) gelse ... gibi). [kaçan $+-(y)$ $s A]$ kombinasyonu melez yapılar bahsinde dahil olduğundan bu tür örnekleri buraya almadım.

\section{- vaḳtī ki / vaḳtā ki}

Cümleleri birbirine zaman fikri ile bağlamak, içinde Arapça waqt 'vakit' kelimesi barındıran öncü bağlaçlarla da mümkün. Bunlardan birisi vaktī ki. Bağlaç bu şekliyle Farsçada da mevcuttur. Aşağıdaki Türkçe ilk örnek 15. yüzyıldan. Osmanlı Türkçesinin daha sonraki devirlerinde daha ziyade, Farsçada pek tercih edilmeyen vakt $t a \bar{~} k i$ şeklinde görülüyor. ${ }^{36}$

Bağlaç, zaman zarf cümlesini ana cümleye $[-D I K+$ iyelik + zaman; $-D I K+$ iyelik + lokatif; -(y)IncA] anlamlanyla bağlıyor. Meninski vaḳtā ki için "tunc quando" "ne zaman (ki) ... o zaman ...; -(y)IncA' karş11 Ĭğın veriyor. ${ }^{37}$

vaktĩ ki (hālet-i rucūliyete èrişdi) (atasınuy 'ammūları kızından tezvīc èdüp evlādl old $l$ ) [erişince]

vaktā ki (eceli yète) (bu hilkat üzere helāk olur) [yettiği zaman] (Çatıkkaş 2009:187)

vaktā ki (sulțan mehmed han-ı șālis eğri kal'asını feth ve avrupanı kuvve-i 'umūmiyyesini kahr ile istanbula 'avdet eyledi) (... eğri muzafferiyetiniๆ huṣūlüne sebeb olan dāmād ibrāhìm paşa merhūmu 1009 tarihiyle def'a-i sālisede sad̄̄-

36 Krş. Deny, a.g.e., s. 700.

37 Meninski, a.g.e., s. III/5400. 
retle ordu-yı hümāyūna serdār eyledi) [avdet eyleyince/dönünce] (19. yy. Namık Kemal)

Osmanlı Türkçesinde vak(t)t kelimesini ihtiva eden başka yapılar da vardır. Bunlar soru zamiri ne ile kurulur: ne vaḳt ki/kim ya da vasıta eki almış şekliyle ne vaktın ki/kim. Deny'ye göre bunların hepsi aynı işlevi görür ve kaçan'la eşanlamlıdır; Türkler vasıta ekli olanı tercih ederken yabancılar yalın olanı tercih ederler. ${ }^{38}$ Burada Deny'nin dikkatinden kaçan bir hususu belirtmekte fayda var: ne vakıt $\mathrm{ki} / \mathrm{kim}$ ve ne vaktın $\mathrm{ki} / \mathrm{kim}$ daha ziyade yüklemin şart eki almasıyla genelleyici zaman cümleleri kurarken, vaktī ki/vaktā ki kahir ekseriyetle şart ekiyle kullanılmaz (mamafih birkaç istisna da mevcuttur). Bu bağlaç türünün işaret zamirleriyle kurulanı da mevcuttur: ol/şol vakıt ki/kim.

$\mathrm{Bu}$ yap1 varlığını, vakit kelimesinin yerini zaman kelimesine bırakmasıyla günümüz Türkçesinde de sürdürmektedir: "Ne zaman ki lider doğurdu analar1mız, içimizden bir hain çıktı, hançerledi bizi sırtımızdan" (Yeni Şafak, 8 Ocak 2014).

\section{- hemān ki/kim}

Bağlaç, Farsça menşeli hemān ile ki/kim unsurunun birleşmesinden meydana gelmiştir; ki/kim kısmı bitişik de ayrı da yazılabilir. Hemān ki / hemān kim bağlacı ikinci cümledeki (B cümlesindeki) oluşun/eylemin birinci cümledeki (A cümlesindeki) oluş ya da eylemin bitiminin hemen akabinde, ivedilikle gerçekleştiğine dair malumat vererek cümleleri birbiriyle bağlar. Meninski bağlaç için ivedilik/ doğrudanlık ifade eden "statim atque" karşılığını vermişs ('-(y)IncA ... hemen/ derhal ...' manasında). Deny bağlacı haklı olarak ivedilik manası taşıyan "dès que" ile karşılamış; ama ķaçan ile eşanlamı olduğunu ifade ederek hataya düşüyor. ${ }^{40}$ Zira kaçan kendi içinde hususi bir ivedilik anlamı barındırmıyor. Yazarın dikkatinden kaçan ikinci bir husus da hemān ki bağlacının, kaçan'ın aksine şart eki ile kombine edilemeye pek müsait olmayışı ve dolayısıyla genelleyici zaman cümleleri kuramayışıdır.

Bağlaç, günümüz Türkçesinde [-DIK + iyelik + gibi] ya da aynı filin geniş zaman eki ile bir olumlu bir olumsuz olmak üzere tekrarlanmasiyla (mesela gelir gelmez) karşılanabilir.

hemānki (kara rüstem karamandan geldi) (ḥ̄le ve bid'at ḥādis ola başladı) [gelir gelmez]

hemān kim (leşkerüy gitdügin gördiler) (hișārdan çıkmag்a başladılar) [görür görmez]

38 Deny, a.g.e., s. 699-700.

39 Meninski, a.g.e., s. III/5489.

40 Deny, a.g.e., s. 699. 
hemān ki (ot yèrden çıkdı) (anlar öteden bizüm üzerümüze gelür) [çıkar çıkmaz]

Bağlaç, ivedilik fikrini tek başına ifade edebilir. Fakat bazen aşağıdaki örnekte de görüleceği üzere der-hạal gibi aynı fikri veren bir zarf bağlaçla da desteklenebilir.

hemān ki (küffār 'askerini gördi) (der-hāal atından indi) [görür görmez]

Hemān Farsçada olduğu gibi Türkçede de birden çok anlamı ve fonksiyonu olan bir kelimedir; hem 'gibi, aynı/aynen, bir' ve ān 'o' işaret zamirinden müteşekkildir. Fakat ke 'ki' ile kombine edilmiş bir öncü bağlaç olarak Farsçada kullanılmaz (Ben Türkçe, Farsça, Almanca, İngilizce ve Fransızca olarak kaleme alınmış onlarca gramer kitabı ve lügatte rastlamadım). Bu sebeple bağlacın daha ziyade Farsça kaidelere göre teşkil edilmiş bir Türk icadı olduğunu söylesek yerinde olur. İvedilik anlam ilişkisini ihdas etmek için kaynak dil Farsçada daha ziyade hamīn ke (ham + in 'bu' + ke) göze çarpar. ${ }^{41}$ Buna mukabil hemīn ki Osmanlı Türkçesi metinlerinde neredeyse hiç kullanılmamaktadır.

Kuruluş itibarıyla hemīn ile hemān arasındaki biçimsel tek fark, işaret zamirinin ìn 'bu' ya da ān 'o' oluşudur. Osmanlı Türkçesinde hemān' ın (Türkiye Türkçesinde hemen) diğer anlamlarının ve işlevlerinin yanı sıra ivedilik ifade eden bir zarf bağlaç olarak öne çıkmasının, tercih edilmesinin sebebi kanaatimce, hemān içindeki $\bar{a} n$ 'o' zamirinin Arapçadaki ān 'zaman, vakit, an' ismi ile hem yazıllış hem de söyleyiş bakımından aynı olması ve bunun da Türklerde bir zaman fikri tedai ettirmesidir. Nitekim hemān Farsçada tek başına ivedilik manası taşıyan bir zaman zarfı olarak kullanılmazken Türkçede bu mana ve fonksiyonda yaygın bir şekilde kullanılır; Farsçada hemān ivedilik manası için zaman/vakit ifade eden başka bir kelimeye daha ihtiyaç duyar: hemān-dem, hemān-sā 'at gibi ki Osmanlı Türkçesinde hemān'ın yanında bu şekiller de mevcuttur.

\section{- mādām ki}

Türkçeye Farsçadan geçen bu bağlaç, Arapça menşeli unsur māa-dām(e) $)^{42}$ 'sürmekte olan, devam etmekte olan' ile ki unsurunun birleşmesinden oluşur. Farsçadaki şekli mādāmī ke'dir. Osmanlı Türkçesinin ilk devrelerinde Farsçada olduğu gibi $[-D I K+$ iyelik + sürece/müddetçe $]$ manasını taşır ve zaman zarf cümlesini temel cümleye bağlar. Meninski "daim oldukçe ... durante, quamdiu" şeklinde bir karşılık veriyor. ${ }^{43}$ Bağlacın kim'li şekline rastlamadım.

mādām ki ('osmān og̀lınun ḳapusı ve ḳapu ḳulları biledür) (aךa cevāb ver-

41 Bu hususla ilgili krş.; Gilbert Lazard, Grammaire du Persan contemporain, Paris, 1957; Jensen, a.g.e.; Alavi \& Lorenz, a.g.e; Amin-Madani \& Lutz, a.g.e.

42 Arapça ilgi zamiri $m \bar{a}$ 'ne (ne ki)' ile mazi fiil dāme 'devam etti' kelimelerinden müteşekkildir.

43 Meninski, a.g.e., s. III/4230. 
mek müşlikdür) [birlikte olduğu müddetçe]

mādāmki (karaman og̀lı karamanda begdür) ('avrat og̀lan bizüm degüldür) [bey olduğu müddetçe]

Bağlaç, takriben 19. yüzyılda anlam değişmesine uğramış ve [-DIK + iyelik + sürece/müddetçe] anlamıyla zaman ilişkisi kuran manasını kaybetmiştir ${ }^{44}$; $\operatorname{art}^{1 \mathrm{k}}$ önermeler arasında izafi bir sebep-sonuç ilişkisi kurmaktadır. Günümüz Türkçesinde ise madem, madem ki şeklini almıştır. Türkiye Türkçesinin ender öncü bağlaçlarındandır; bununla birlikte konumu, Karnın çok aç madem, git bir simit al! cümlesinde olabileceği gibi artık değişkendir.

\section{- eger / ger}

Şart cümleleri Türkçede şart eki -(y) $s A$ yardımıyla kurulur. Farsçadan alınmış olan eger/ger ( $>$ e ğer) zaruri olmamakla birlikte şart cümlesi bünyesinde genellikle bulunur. Eski Anadolu ve Osmanlı Türkçesi devrelerinde eger, şart eki alan cümlelerin yanında, istek kipi taşıyan yüklemlerle de şart cümlesi kurabiliyordu. $\mathrm{Bu}$ durum günümüz Türkçesinde tercih edilmemektedir. Şart eki taşıyan eger'li örneklere bu makalede yer verilmedi. Zira Türkçede şart eki taşıyan yüklemler eger'e ihtiyaç duymadan da şart cümlesi kurabilmekte ve bu surette yan cümle ana cümleye bağlanabilmektedir. [eger $+-(y)_{s A}$ ] kombinasyonunu barındıran cümleler melez yapılardır. Melez yapılara iştirak eden bağlaçların başka bir kategoride incelenmelerinin daha uygun oluğunu belirtmiştim.

eger (ahsen-i riżāyla ele girüp ol yaramaz işden fārig olup tevbe èdüp bāb-l sa 'ādet-me'àbumda hidmet ède) (aya ben dahı eyü dirlik èdem) [hizmet ederse]

eger (șatmaya) (hīç nesne vermesün) [satmazsa]

eger (hünkār ben kulına bir bahādur kulın koşa) (varayın bosna vilāyetin tamām alıvèrüp müslimānları ganī kılayın) [koşarsa/emrime verirse]

Yukarıdaki metinlerden eger bağlacı sakıt olursa cümleler arasındaki şart-cevap ilişkisi de ortadan kalkar. Fakat bu cümleler bir de şart eki ihtiva ediyor olsalard1, o zaman eger hazfedilse dahi şart-cevap münasebeti baki kalırdı.

İfade edilmesi gereken hususlardan biri de günümüz Türkçesinde e ğer'in pozisyonunun eskiden olduğu gibi artık sabit olmadığıdır. Bunun için 'Akşam eve erken gitmeyeceksen ĕger, birlikte bir çay içelim' örneğini verebiliriz. Burada bağlacın yüklemden sonra pozisyon alması ilgi çekicidir.

\section{- her çend ki}

Başka bir öncü bağlaç [-mA + iyelik + datif + rağmen/karşın $]$ gibi zıtlık/kar-

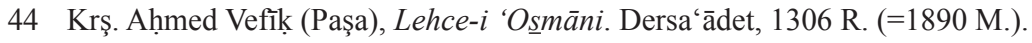


şıtlık anlamıyla yan cümle (concessive clause) kuran her çend ki. Bu bağlaç da Farsçadan kopya edilmiş; teşekkülünde her + çend 'kaç? ne kadar?' + ki ihtiva ediyor. Çok sık kullanılmamakla birlikte Osmanlı Türkçesi metinlerinde görülmektedir.

her çend ki (çalışdı) (alayını düzmek mümkin olmadı) [çalışmasına rağmen/ çalışsa da]

Her çend ki'yi günümüz Türkçesinde aynı anlamda kullanılan öncü bağlaç her ne kadar ile mukayese edebiliriz. Anlaşılan o ki, her ne kadar söz konusu bağlacın Türkçeye birebir aktarımından başka bir şey değil. Bu bağlaç da öncü bir bağlaçtır; başındaki her kısmını olmadan da kullanılabilmektedir. Yalnız, (her) ne kadar (da) gayret etse (de) başarılı olamadı cümlesinde olduğu gibi şart eki (ve çoğunlukla yeri değişebilen bir $d A$ ) ile bir kombinasyona ihtiyaç duyar ve böylece melez cümle kuran bağlaçlar kategorisine dahil olur.

- egerçi / gerçi

Bu bağlaç yukarıda zikredilen Farsça eger ya da onun kısa şekli olan ger ile Farsça çi'den 'ne' teşekkül ediyor. Ki/kim'li şekilleri de olabiliyor. ${ }^{45}$ Bağlaç, zitlık/karşıtlık ifade eden yan cümlelerin (concessive clauses) teşekkülünde kullanıliyor ve bunun için ayrıca ara pozisyonda yer alan bir ammāa, lākin, fakat unsuruna ihtiyaç duyuyor. Böyle ammā, lākin gibi aracı bir bağlaçla birlikte kullanılması cihetiyle de diğer öncü bağlaçlardan ayrılan bir tarafı var. Farsçadan sadece bağlacın kendisinin kelime olarak kopya edilmediği, bilakis içinde kullanıldığı ifade kalıbıyla birlikte kopya edildiği, burada da aşikardır. ${ }^{46}$

egerçi (bunlar zamānen ve żikren mu'ahhardur) ammā (rütbeten ve kadren mukaddemdür) [muahhar (sonradan gelen) olmakla birlikte]

Günümüz Türkçesinde bu yapı 'gerçi... ama...' şeklindeki bir kombinasyonla yaşamaktadır. Bu kombinasyonun İngilizcede yapısal anlamda birebir bir karşı11ğ1 yok; bununla birlikte tercümelerde 'even if, although' gibi bağlaçlar kullanılabilir. Fakat gerçi-ama kombinasyon kalıbı, Almancanın zwar-aber kombinasyon kalıbıyla hem yapısal hem de içerik bakımdan büyük bir benzerlik arz ediyor.

\section{- anuniçün ki/kim}

Listenin son bağlacı olan anuฑiçün ki/kim, çoğunlukla cümleler arasında sebep-sonuç (causality) ilişkilerini ifade etmek için kullanılır. Bununla birlikte -yüklemin kipine ya da bitimsizleştirilme şekline bağlı olarak- bazen amaç

45 Bkz. Kamil Tiken, Eski Türkiye Türkçesinde edatlar, bağlaçlar, ünlemler ve zarf fiiller, TDK 837, Ankara, 2004.

46 Farsçadaki yapı için bkz. mesela Jensen, a.g.e., s. 305. 


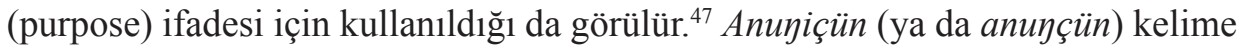
olarak Türkçe menşeli bir birleşik yapıdır; anuๆ 'onun' zamiri ile son çekim edat1 içün'den müteşekkildir. Eski Anadolu ve Osmanlı Türkçesi devrelerinde zarf bağlaç olarak sıklıkla kullanılır. Bu zarf bağlaca ki/kim unsurunun eklenmesi ile de gerçek bağlaç teşekkül eder. ${ }^{48}$ Bağlaç, teşekkülündeki unsurlar ve kullanım alanları itibarıyla Farsçadaki barāy-e in ke 'için+ genitif+ bu+ ki' ile benzerlikler arz etmektedir.

Anuiiçün ki/kim, Eski Anadolu ve Osmanlı Türkçesi devrelerinde yaygın olarak aracı bağlaç vazifesi görmekteydi . Mamafih nadir de olsa, buradaki birkaç örnekte görüleceği gibi, öncü konumda kullanıldığ vakidir. Öncü pozisyondaki kullanımın sadece, bağlacın sebep cümlesinin başına geldiği durumlarda mümkün olduğunu düşünüyorum; bağlacın amaç cümlesi kurması durumunda öncü olarak kullanılabilme ihtimali pek yok gibi.

Bağlacın öncü konumda kullanıldığı durumlarda (A) cümlesi sebebi, (B) cümlesi de onun sonucunu bildirir.

anuyiçün kim (vilāyetüy a yānları bāyezīd hana adam göndürdilerdi gel dèyü) (bāyezìd han dahı sürdi sivaza geldi) [gönderdikleri için]

anuyiçünkim (gendü mānendi 'askeri saya ḳoşmışdı) (imdi çobanlık dah̆ı senü̈dür) [koştuğu/emrine verdiği için]

anuyiçünkim (bu ḳara tigin hișārı içinde olan gāā̄ler dāyim iznikụ ḳapusını açdurmazlarıdı) (bejāyet aclıkdan buyalmışlardı) [açtırmadıkları için]

47 Ahmet Şefik Şenlik, "Eski Anadolu Türkçesinde anuniçün ve anuniçün ki/kim hakkında", İstanbul Üniversitesi Edebiyat Fakültesi, Türk Dili ve Edebiyatı Dergisi, vol.46, no.46, 2012b., s. 121-128.

48 Ayrıntılı bilgi için bkz. Şenlik, a.g.e., 2006 ve 2012 b. 


\section{Sonuç}

Bu makalede birleşik cümleler içerisinde aldıkları pozisyona göre öncü bağlaç olarak adlandırdığım bir bağlaç grubunun Osmanlı Türkçesi metinlerindeki genel kullanım temayülleri ele alınmış bulunuyor. Önermeler, öncü bağlaçlar vasıtasıyla, Türkçenin asli yapısında bulunmayan bir teknikle zaman, sebep-sonuç, şart, karşıtlık gibi muhtelif semantik kategorilerle birbirlerine bağlanmaktadır.

Öncü bağlaçların konumlarının burada örneklerde gözlemlenen kanonik vaziyetin dışına çıkması da muhtemeldir. Önermelerin/cümlelerin takdim-tehir edilmesi ile tabii olarak bağlacın pozisyonu da değişebilir. Bu takdim-tehir tercüme metinlerde orijinale uygunluk kaygıs1, bir fikri bir surette vurgulama arzusu ya da bir fikrin sonradan ilave edilmesi gibi saiklerle meydana gelebilir.

Eski Anadolu ve Osmanlı Türkçesinde çok sayıda bulunan öncü bağlaçtan Türkiye Türkçesinde sadece madem(ki), ne zaman (ki), her ne kadar vs. gibi birkaçı hayatta kalabilmiştir. Bunlardan madem (ki) yakın denilebilecek biz zamanda anlam değişmesine maruz kalmıştır. Öncü bağlaç çūn ki/kim, konum değiştirerek aracı bağlaç çünkü haline gelmiş ve yine bir anlam daralmasına uğramıştır. Günümüz Türkçesi, öncü bağlaçların konumlarını da nisbeten daha serbest hale getirmiştir. Yukarıda ifade edildiği gibi eğer, çünkü, madem (ne zaman ki hâlâ sabit bir konuma sahip ve buraya dahil değil) gibi bağlaçların yüklemden sonra bile kullanılabiliyor oluşu ilgi çekici bir dil hadisesidir, 'Okula gidemedim. Çok hastaydım çünkü' gibi.

Daha evvel zikrettiğim gibi, öncü bağlaçların başka bir kategoride/makalede ele alınması gerektiğini düşündügüm melez cümle bağlama yapılarında kullanıldığı da vakidir. Osmanlı Türkçesinde öncü bağlaçların iştirakiyle oluşan melez yapılara örnek olmak üzere benim rastladıklarımdan bazıları şöyle kısaca zikredilmiş olsun: çūnki/kim: -(y)Up, -(y)IcAK, -dUKdA, -dUK(In)dAn, -ken; hemān ki/kim: $-d U K d A$, $-d U G I$ gibi, $-d U G I$ birle; eger: $-(y) s A$; ḳaçan: $-(y) s A$; ne vaktın ki/kim: $-(y) s A$; mādām ki: $-d U K c ̧ A$; anuyiçün ki/kim: -mAGiçün vs. (krş. Şenlik 2006).

Türk kavimleri İslamiyet'in kültür havzasına dahil olduktan sonra bu havzada bulunan birtakım kelimeleri ihtiyaca binaen dillerinde kullanmaya başlamıştır. Bu havzanın iki önemli dili Arapça ve Farsçadır. Dolayısıyla Arapça ve Farsça kelimelerin varlığı Türk dilinin İslam sonrası tarihî devrelerinde farkı yoğunlukta hep hissedilir. Güneybatı grubu ve bu grubun içinde bulunan Türkiye Türkçesi ile onun tarihî uzantıları Eski Anadolu Türkçesi ve Osmanlı Türkçesi de bundan berî değildir. Bu noktada basmakalıp ifadelerle kimi zaman zikredilen iki yanlış kanaati de bertaraf etmek lazım. Bunlardan ilki, Türkçenin (özellikle Osman11 Türkçesinin) Arapçadan ve Farsçadan yoğun bir şekilde etkilendiğidir. Daha önce de çeşitli vesilelerle dile getirdiğim gibi Türkçenin Arapçadan doğrudan 
etkilenmesi ancak asgari düzeydedir; yani Arapça kökenli kelimeler Türkçede (özellikle Osmanlı metinlerinde) hayli miktarda bulunsa da Arapçanın Türkçe üzerinde baskın bir tesiri yoktur. Arapça unsurlar Türkçeye umumiyetle Farsça vasıtasıyla, bu dilin süzgecinden geçerek girmişlerdir. Osmanlı Türkçesini derinden etkileyen dil aslında sadece Farsçadır. İkinci yanılgı, Türkçenin sadece leksikal bir tesire maruz kaldığ 1 , sentaksının muhkem olduğu, başka bir dilin (Farsçanın) sentaksından pek etkilenmediğidir. Bu görüş, birçok başka veriyle birlikte eldeki bu makalenin de gösterdiği gibi doğru değildir. Farsça etkisi, Eski Anadolu Türkçesinde mevcut olan, Osmanlı Türkçesi devresinde yoğunlaşan ve günümüz Türkçesinde tamamen yok olmayan, hala yaşayan bir olgudur; üstelik sadece leksikal anlamda değil, sentaktik ve semantik bakımdan da. Farsçadan kelime, gramer unsurları ve teknikleri almak, hem yüzyıllardan beri İran halklarıyla ve dilleriyle aynı coğrafyayı paylaşıp münasebette bulunmuş olmak hem de tipolojik benzerlikler hasebiyle -Arapçaya nisbetle- kolay olmuştur. 


\section{Kaynakça}

Adamović, Milan, Floransalı Filippo Argenti'nin notlarına göre (1533) 16. yüzyıl Türkçesi, (terc. Aziz Merhan). TDK yayınları: 415, Ankara, 2009.

Ahmed Cevdet (Paşa), Belāgàt-ı 'Osmāniye, İstanbul, 1298 R. (=1882 M.).

Aḥmed Vefîk (Paşa), Lehce-i 'O $\underline{s} m a \bar{n} n i$. Dersa'ādet, 1306 R. (=1890 M.).

Alavi, Bozorg \& Lorenz, Manfred, Lehrbuch der persischen Sprache. Leipzig, Berlin, München, Wien, Zürich, New York, 1994 .

Amin-Madani, Sadegh \& Lutz, Dorothea, Persische Grammatik. Heidelberg, 1972.

Bulut, Christiane, Evliya Çelebis Reise von Bitlis nach Van. Ein Auszug aus dem Seyahatname. (= Turcologica 35, yay. haz. Johanson, L.). Wiesbaden, 1997.

Clauson, Sir Gerard, An etymological dictionary of pre-thirteenth-century Turkish. Oxford, 1972.

Çatıkkaş, M. Atâ, Firdevsî-i Rûmî, Süleymannâme-i Kebîr, TDK 974, Ankara, 2009.

Deny, Jean, Grammaire de la langue turque (dialecte Osmanli), Paris, 1921.

Erdal, Marcel, A grammar of Old Turkic. Leiden, Boston, 2004.

Grönbech, Kaare, Der türkische Sprachbau. Kopenhagen, 1936.

Hac1eminoğlu, Necmettin, Türk dilinde edatlar, İstanbul, $1992^{4}$.

Hazai, György, Das Osmanisch-Türkische im XVII. Jahrhundert, Untersuchungen an den Transkriptionstexten von Jakab Nagy de Harsány. Budapest, 1973.

Horn, Paul, Grundriss der neupersischen Etymologie. Strassburg, 1893.

Jensen, Hans, Neupersische Grammatik. Heidelberg, 1931.

Johanson, Lars, Strukturelle Faktoren in türkischen Sprachkontakten. (=Sitzungsberichte der Wissenschaftlichen Gesellschaft an der J. W. Goethe Universität Frankfurtam Main, 29:5), Stuttgart, 1992.

—_, "Typen kausaler Satzverbindungen im Türkischen", Journal of Turkology 1 (2), yay. haz. Berta, Á. \& Molnár, Á., Szeged, 1993, s. 213-267.

, "Kopierte Satzjunktoren im Türkischen", Sprachtypol. Univ. Forsch. (STUF), 49 (1996)-1, 1996, s. 39-49.

Kerslake, Celia, "Ottoman Turkish", The Turkic Languages, ed. by Johanson, L. \& Csató, E. Á., London, 1998, s. 179-202.

K1ral, Filiz, Syntaktische Einflüsse des Persischen auf das gesprochene Aser- 
baidschanisch von Iran. [Diss.], Mainz, 1997.

Kowalski, Tadeusz, Sir Aurel Stein's Sprachaufzeichnungen im Äinallu Dialekt aus Südpersien (= Polska Akademia Umiejętności. Prace Komisji Orientalistycznej - 29.), 1937.

Lazard, Gilbert, Grammaire du Persan contemporain, Paris, 1957.

Mansuroğlu, Mecdut, "Türkçede cümle çeşitleri ve bağlayıcıları”, Türk Dili Araştırmaları Yıllığı-Belleten 1955, Ankara, 1955, s. 59-71.

Mehmed Rif'at (Manastırlı), H'āce-i lisān-ı 'Oșmānī, 2 (Naḥv-i Türkī), Dersa'ādet, 1311 R. (=1893 M.).

Menges, Karl Heinrich, Das Čagatajische in der persischen Darstellung von Mìrzā Mahdī Xān. (= Akademie der Wissenschaften und der Literatur, Abhandlungen der geistesund sozialwissenschaftlichen Klasse, 1956 - 9), Wiesbaden, 1956.

Meninski, Franciscus à Mesgnien, Thesaurus Linguarum orientalium turcicae-arabicae-persicae, lexicon turcico-arabico-persicum. Tıpkıbasım (2000) M. Ölmez \& S. Stachowski, İstanbul, 1680.

Römer, Claudia, "Der Einfluss der Übersetzungen aus dem Persischen auf die Entwicklung des Osmanischen im 14. und 15. Jahrhundert", Wiener Zeitschrift für die Kunde des Morgenlandes 73 (Wien), 1981, s. 89-114.

Serebrennikov, B. A. \& Gadžieva, Ninel Z., Sravnitelno-istoriçeskaya grammatika tyurskih yazıkov, sintaksis. Moskva, 1986.

—, Türk yazı dillerinin karşılaş̧tırmall-tarihi grameri. (terc. Hacıyev, T. \& Öner, M.). TDK yayınlar1 1033, Ankara, 2011.

Şahinoğlu, M. Nazif, Farsça grameri. Sarf ve nahiv, İstanbul, 1997.

Şenlik, Ahmet Şefik, Zur Satzverknüpfung im Altosmanischen unter besonderer Berücksichtigung der interpropositionalen Kausalität. [diss.], Mainz, 2006.

, "Eski Anadolu ve Osmanlı Türkçesinde cümle bağlaçlarının tasnifine dair bazı öneriler", İstanbul Üniversitesi Edebiyat Fakültesi, Türk Dili ve Edebiyatı Dergisi, vol. 45, no. 45 (2011), 2012a, s. 251-268.

- "Eski Anadolu Türkçesinde anuniçün ve anuniçün ki/kim hakkında", İstanbul Üniversitesi Edebiyat Fakültesi, Türk Dili ve Edebiyatı Dergisi, vol.46, no.46, 2012b, s. 121-128.

Temir, Ahmet, "Konjunktionen und Satzeinleitungen im Alt-Türkischen 1", Oriens 9, 1956a, s. 41-85

_ , "Konjunktionen und Satzeinleitungen im Alt-Türkischen 2", Oriens 9, 1956b, s. 233-280. 
Tiken, Kamil, Eski Türkiye Türkçesinde edatlar, bağlaçlar, ünlemler ve zarf filler. TDK 837, Ankara, 2004.

Underhill, Robert, Turkish grammar, Cambridge, Mass. \& London, 1976.

Vámbéry, Hermann, Etymologisches Wörterbuch der Turko-Tatarischen Sprachen, Leipzig, 1878. 
